【総説】

\section{看護における補完代替医療の 現状と問題点}

一ホスピス・緩和ケア病棟に勤務する 看護師の補完代替医療の習得と 実施に関する調査から一

\section{Level of Awareness and Practice of Complementary and Alternative Medicine in Nursing}

-Survey of Nurses in Palliative Care
Unit with Regard to Training and
Practice of Complementary and
Alternative Medicine-

新田紀枝 ${ }^{1, *}$, 川端京子 ${ }^{2}$ Norie NITTA ${ }^{1, *}$, Kyoko KAWABATA ${ }^{2}$

1 大阪大学大学院医学系研究科保健学専攻
2 大阪市立大学医学部看護学科

\section{【要 旨】}

緩和ケア病棟の看護師による補完代替医療 (CAM) の 習得と実施の現状を明らかにすることを目的に全国調 査を行った. 調査票は看護師 907 名（回収率 $77.3 \%$ ) から回収された. 9 割の者が看護ケアとして CAM を 実施したことがあり，CAM の関心，身体的，精神的効 果の認識, 必要性の認識はいずれも高かった. 看護基 礎教育で学習する機会があったマッサージや足浴，罨
法がよく実施されていた. 身体的, 精神的症状に応じ て異なる CAM が使用されていた. 実施上の問題点と して「技術が未熟」,「時間の不足」,「効果の評価がで きていない」があげられた. CAM の習得上の要望に は, 講習会の開催に関するものが多かった. 看護ケア として CAM を実施していくためには，各種 CAM の エビデンスの蓄積と看護基礎教育, 継続教育における CAM の教育プログラムの充実が必要であると考えら れた.

【キーワード】

緩和ケア病棟，看護ケア，補完代替医療，看護師

\section{I. はじめに}

看護に扮ける補完代替医療 (Complementary and Alternative Medicine; 以下CAM) は，10 数年前に米国から 看護独自の介入 ${ }^{1)}$ として，わが国に紹介された．患者の 身体的，精神的苦痛を癒すことを目的に実施されている マッサージやタッチングなどその CAM の多くは，わが 国の看護師がそれと意識せずに経験的に行ってきた看護 ケアが多く含まれていた，そのため，看護における CAM は，看護介入の方法としてわが国の看護師に受け入れや すい状況にあった。 さらに，CAM は身体的苦痛の緩和 のみならず，心理面や社会面にも影響を及ぼし，QOL の 向上にも寄与すると考えられ，瘉しの技術として多くの 看護師が関心を持つょうになった。

看護師が CAM を日常の看護ケアの中に取り入れ，実 践していくためには，それに関連した知識と技術を身に つける必要がある。しかし，看護基礎教育や継続教育に おいて CAM に関する教育を行っているところは少な く，専門的な看護ケアとして系統立てられた CAM の教 育プログラムはほとんどない.そのような状況の中で， 看護師が看護ケアとして CAM をどのようにとらえ, 実 施しているか，また看護師が CAMをどのように習得し ているのかといら疑問をもった，欧米に拈いても，看護 師が看護ケアとして実際に行っている CAM について報 告されたものはなかった

そこで，看護ケアとして CAM をよく実施していると 考えられるホスピス・緩和ヶア病棟（以下，緩和ヶア病 棟）に执いて，看護師によるCAM の習得と実施の現状 を明らかにすることを目的に全国調査を行った。

本稿ではその調査の結果から，看護における CAM の 現状と問題点について述べていきたい.

\footnotetext{
受理日：2007 年 1 月 9 日

* =565-0871 大阪府吹田市山田丘1-7 大阪大学大学院医学系研究科保健学専攻 Tel \& Fax: 06-6879-2535

E-mail: norien@sahs.med.osaka-u.ac.jp
} 


\section{II. 本調査における CAM の定義}

看護ケアとして行われている CAM の多くは，米国の 国立衛生研究所 $(\mathrm{NIH})$ ・国立補完代替医療センター (NCCAM) のCAM の分類に扣いて, 用手療法（指圧, マッサージ療法, タッチ療法なぞ), 心身のコントロール （リラクセーション法，イメージ法など）に含まれるもの である.

本研究で使用している CAM は，患者のセルファアの 促進, 症状の緩和を目的に, 看護師の自律的な判断のも とに行われる看護ケアを意味する. Snyder $ら^{2)}$ の看護に 使う補助的・代替的療法を参考化して選定した漸進的筋 弛緩法, 自律訓練法, 呼吸法, マッサージ, 罨法, セラ ピューティックタッチ, 意図的タッチ, 瞑想療法, イメー ジ療法, バイオフィードバック, 催眠療法, 音楽療法, アロマセラピー, ペットセラピー, 日記療法, 回想療法, 読及語り療法の 17 項目, 打よびわが国でよく行われてい る足浴，近年実施されるようになったリンパドレナージ を加えた計 19 項目を指す。

\section{III. 調査の概略}

対象者は, 日本ホスピス緩和ケア協会A会員である 146 施設（平成 17 年 7 月 1 日現在）に対して調查協力を依頼 し, 調查の承諾を得た 77 施設の緩和ケア病棟に勤務して いる看護師 1174 名である.

調査の内容は，個人属性，CAM の関心，効果，必要 性の認識の程度, CAM の習得方法, 実施目的と使用寸 る CAM の種類，実施する上で問題点，今後身につけた いCAM, CAM を習得する上での要望などである.

\section{IV. 対象者の属性}

調査票は看護師 907 名から回収され，回収率は $77.3 \%$ であった。

年齢の平均は 35.3 歳（標準偏差 7.9），看護職の経験年 数の中央値は 10.6 年 $[25 \%$ タイル值; $7.4,75 \%$ タイル 值; 16.5$]$, 緩和ケア病棟の経験年数の中央值は 2.3 年 $[25$ \%タイル值； $2.3 ， 75 \%$ タイル值； 4.3]であり，女性が 891 名 (98.2\%) であった. 看護師長などの職位がある者 が 110 名 (12.1\%) であった。

専門看護師（がん看護）が 2 名 $(0.2 \%)$, 認定看護師 が 34 名（3.7\%）であり，内訳は緩和ケアが 17 名（1.9 \%)，がん性疼痛看護が 14 名 (1.5\%)，その他であった。 CAM に関する資格はアロマセラピーに関するものが 29 名 (3.2\%) で最も多く, リフレクソロジストが 7 名 $(0.8$
\%),リンパドレナージセラピストが 4 名 (0.4\%) であっ た

\section{V. 緩和ヶア病棟における CAM の現状}

\section{1. 実施したことのある CAM（表 1）}

看護ケアとして CAM を実施したことのある者は 824 名(90.8\%) であった．CAM を実施したことがある者は， ない者と比較して緩和ケアの経験年数が有意に長かった $(\mathrm{p}=0.013)$ ．その他に，実施の有無と属性の項目に差は認 められなかった。

看護ケアとして実施したことがある CAM は, マッ サージが 773 名 (93.8\%) で最も多く，次いで足浴が 719 名 $(87.3 \%)$, 罨法が 648 名 $(78.6 \%)$, 意図的タッチが 481 名 (58.4\%)，アロマセラピーが 354 名 (43.0\%)，リ ンパドレナージが 298 名 (36.2\%), 呼吸法が 279 名 (33.9 \%）であった.

2. CAM の関心，効果および必要性の認識（表 2，3）

CAM に関心があると回答した者は 844 名 (93.1\%) で あった。

身体的症状に関して CAM は効果があると回答した者 は 875 名（96.5\%）であった。精神的苦痛に関して CAM の効果はあると回答した者は 893 名（98.5\%）で，身体

表 1 実施したことがある補完代替医療

$\mathrm{n}=824$ （複数回答）

\begin{tabular}{lr}
\hline 実施有の項目 & $(\%)$ \\
\hline マッサーシ & $773(93.8)$ \\
足浴 & $719(87.3)$ \\
罨法 & $648(78.6)$ \\
意図的タッチ & $481(58.4)$ \\
アロマセラピー & $354(43.0)$ \\
リンパドレナージ & $298(36.2)$ \\
呼吸法 & $279(33.9)$ \\
音楽療法 & $144(17.5)$ \\
ヘットセラピー & $108(13.1)$ \\
自律訓練法 & $22(2.7)$ \\
読み語り療法 & $22(2.7)$ \\
回想療法 & $19(2.3)$ \\
セラピューティックタッチ & $14(1.7)$ \\
イメージ療法 & $14(1.7)$ \\
漸進的笳弛緩法 & $10(1.2)$ \\
日記療法 & $8(1.0)$ \\
瞑想療法 & $3(0.4)$ \\
催眠療法 & 1 ( \\
その他* & $26(3.1)$ \\
\hline
\end{tabular}

*リフレクソロジー 8 , 指圧 4 , 温尒 4 など

引用文献 3) 144 頁より引用一部改変 
表 2 補完代替医療の関心の程度と効果, 必要性の認識

$\mathrm{n}=907$

\begin{tabular}{|c|c|c|c|c|}
\hline & & 人 $(\%)$ & 再 掲 & 人 $(\%)$ \\
\hline \multirow{7}{*}{ 関心 } & \multirow{4}{*}{ あり } & \multirow{4}{*}{$844(93.1)$} & 非常にある & $118(13.0)$ \\
\hline & & & かなりある & $217(23.9)$ \\
\hline & & & まあまあある & $413(45.5)$ \\
\hline & & & 少しある & $96 \quad(10.6)$ \\
\hline & \multirow{2}{*}{ なし } & \multirow{2}{*}{$59(6.5)$} & あまりない & $53(5.8)$ \\
\hline & & & 全くない & $6(0.7)$ \\
\hline & 無回答 & $4(0.4)$ & & \\
\hline \multirow{7}{*}{$\begin{array}{l}\text { 身体的症状 } \\
\text { の緩和効果 }\end{array}$} & \multirow{4}{*}{ あり } & \multirow{4}{*}{$875 \quad(96.5)$} & 非常にある & $79(8.7)$ \\
\hline & & & かなりある & $328(36.2)$ \\
\hline & & & まあまあある & $375(41.3)$ \\
\hline & & & 少しある & $93 \quad(10.3)$ \\
\hline & \multirow{2}{*}{ なし } & \multirow{2}{*}{$26(2.9)$} & あまりない & $25(2.8)$ \\
\hline & & & 全くない & $1(0.1)$ \\
\hline & 無回答 & $6(0.7)$ & & \\
\hline \multirow{7}{*}{$\begin{array}{l}\text { 精神的症状 } \\
\text { の緩和効果 }\end{array}$} & \multirow{4}{*}{ あり } & \multirow{4}{*}{$893 \quad(98.5)$} & 非常にある & 96 (10.6) \\
\hline & & & かなりある & $374(41.2)$ \\
\hline & & & まあまあある & $329(36.3)$ \\
\hline & & & 少しある & $94(10.4)$ \\
\hline & \multirow{2}{*}{ なし } & \multirow{2}{*}{$8(0.9)$} & あまりない & $8(0.9)$ \\
\hline & & & 全くない & $0(0.0)$ \\
\hline & 無回答 & $6(0.7)$ & & \\
\hline \multirow{7}{*}{$\begin{array}{l}\text { 人間関係構 } \\
\text { 築の有効性 }\end{array}$} & \multirow{4}{*}{ あり } & \multirow{4}{*}{$880 \quad(97.0)$} & 非常に有効 & $91 \quad(10.0)$ \\
\hline & & & かなり有効 & $352(38.8)$ \\
\hline & & & まあまあ有効 & $336(37.0)$ \\
\hline & & & 少し有効 & 101 (11.1) \\
\hline & \multirow{2}{*}{ なし } & \multirow{2}{*}{$15(1.7)$} & 無効 & $14(1.5)$ \\
\hline & & & 全く無効 & $1(0.1)$ \\
\hline & 無回答 & $12(1.3)$ & & \\
\hline \multirow{7}{*}{ 必要性 } & \multirow{4}{*}{ あり } & \multirow{4}{*}{$882 \quad(97.2)$} & 非常に必要 & $130(14.3)$ \\
\hline & & & かなり必要 & $413(45.5)$ \\
\hline & & & まあまあ必要 & $270 \quad(29.8)$ \\
\hline & & & 少し必要 & $69(7.6)$ \\
\hline & \multirow{2}{*}{ なし } & \multirow{2}{*}{$10(1.1)$} & 不要 & $9(1.0)$ \\
\hline & & & 全く不要 & $1(0.1)$ \\
\hline & 無回答 & $15(1.7)$ & & \\
\hline
\end{tabular}

引用文献 4) 7-8 頁より引用一部改変

的症状の緩和より多かった.

CAM による緩和の効果があると認識している身体的 症状は下肢のだるさが最も多く711名（78.4\%)，次いで 不眠が 642 名 $(70.8 \%)$, 痛久が 630 名 (69.4\%), 全身倦 忘感が 568 名 (62.6\%) であった. CAM による緩和の効 果があると回答された精神的苦痛は不安が最も多く9割 以上の者は効果があると回答し，抑らつも 5 割の者は効 果があると回答した。

人間関係の構築に CAM は有効であると回答した者が 880 名 $(97.0 \%)$ であり, 看護ケアとして必要性があると
表 3 補完代替医療の効果があると認識している身体的・精神 的症状

\begin{tabular}{|c|c|c|c|}
\hline 効果の認識 & & & $(\%)$ \\
\hline \multirow{11}{*}{ 身体的症状 } & 下肢のだるさ & 711 & (78.4) \\
\hline & 不眠 & 642 & (70.8) \\
\hline & 痛又 & 630 & $(69.4)$ \\
\hline & 全身倦念感 & 568 & $(62.6)$ \\
\hline & 呼吸困難 & 312 & (34.4) \\
\hline & 便秘 & 268 & $(29.5)$ \\
\hline & 腹部膨満 & 177 & (19.5) \\
\hline & 食欲不振 & 147 & $(16.2)$ \\
\hline & 嘔気 & 136 & (15.0) \\
\hline & 嘔吐 & 55 & ( 6.1$)$ \\
\hline & その他 ${ }^{1)}$ & 16 & $(1.8)$ \\
\hline \multirow{5}{*}{ 精神的症状 } & 不安 & 844 & (93.1) \\
\hline & 抑らつ & 471 & (51.9) \\
\hline & せん妄 & 120 & (13.2) \\
\hline & 意識障害 & 42 & $(4.6)$ \\
\hline & その他 ${ }^{2)}$ & 35 & ( 3.9$)$ \\
\hline
\end{tabular}

1) リンパ浮腫 7 , 掻痒感 3 など

2) イライラ 5 , スピリチュアルペイン 4 , 孤独感 3 など 引用文献 4) 7-8 頁より引用一部改变

回答した者が 882 名（97.2\%）であった.

\section{CAMの習得方法（表 4）}

実施したことがある CAM のらち最も実施されていた マッサージは，技術を有する知人から教えてもらったが 179 名 (21.7\%) で最も多く, 看護基礎教育が 140 名 (17.0 \%) であった，次いで実施が多かった足浴，罨法は，看 護基礎教育で習った者がそれぞれ, 64.7\%と57.5\%であっ た。意図的タッチは看護基礎教育で習った者が 1 割あま りであった．アロマセラピーは技術を有する知人に教党 てもらったが 148 名 $(18.0 \%)$ で最も多く，講習会等の 参加が 112 名 (13.6\%) であった.リンパドレナージは 院内の伝達講習会等が 119 名 (14.4\%), 技術を有する知 人に教えてもらったが 112 名 $(13.6 \%)$, 講習会, セミ ナーの参加は 93 名 $(11.3 \%)$ であった.

実施したことがある CAM のらち習得方法が自己流と 回答した者は，マッサージが 157 名 (19.1\%) で最も多 く，次いで意図的タッチが 136 名 (16.5\%) であった. マッサージは他の習得方法に合わせて自己流といら回答 が多かったが，意図的タッチは他の習得方法がなく自己 流と回答したものが多かった。

\section{4. よく実施する CAM とその実施目的（表 5）}

看護ケアとして実施する CAM のうち，実施すること が多い順に3つあげてもらった結果，よく実施する CAM 


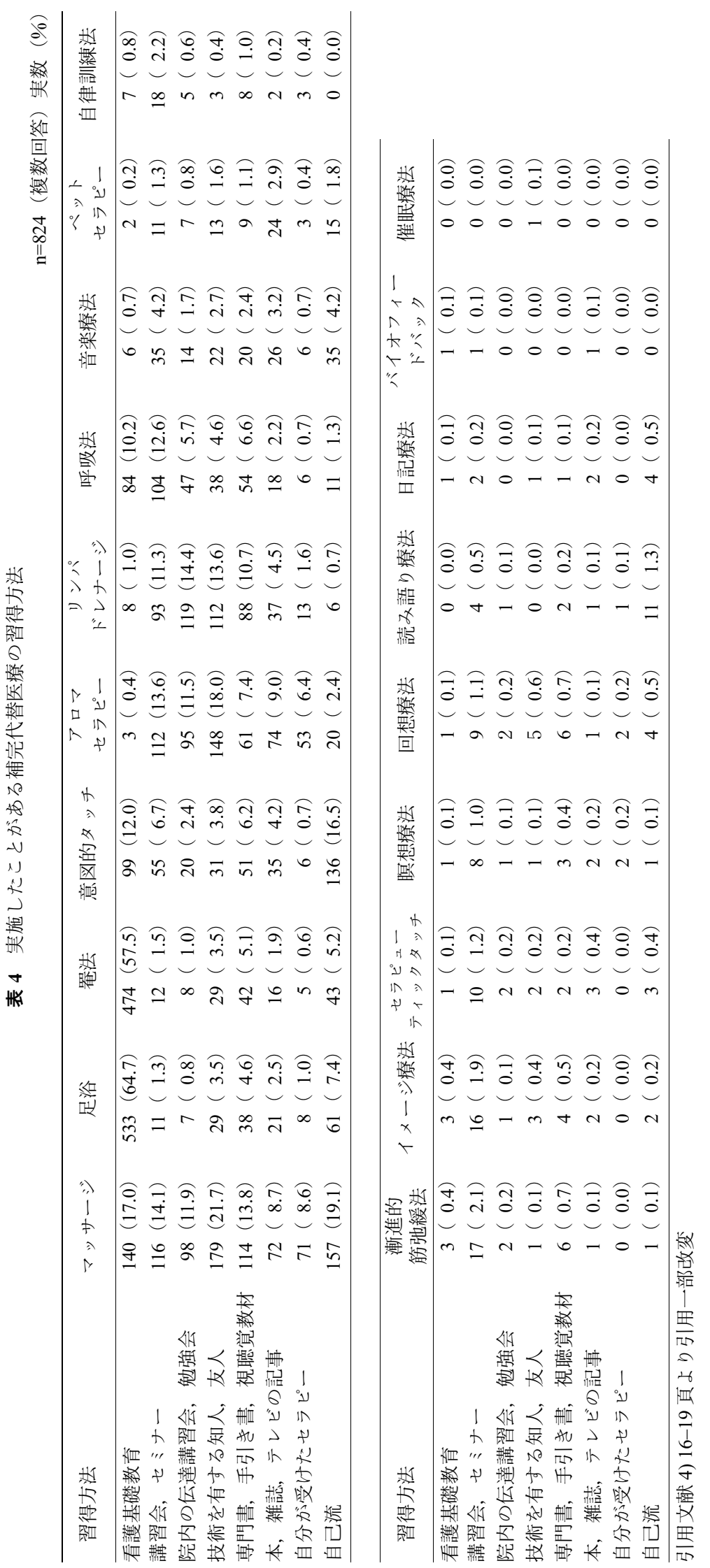


表 5 よく実施する補完代替医療 $\mathrm{n}=824$ （複数回答）

\begin{tabular}{lr}
\hline 療 法 & 人数 $(\%)$ \\
\hline マッサージ & $592(71.8)$ \\
罨法 & $357(43.3)$ \\
足浴 & $335(40.7)$ \\
意図的タッチ & $292(35.4)$ \\
アロマセラピー & $148(18.0)$ \\
リンパドレナージ & $80(9.7)$ \\
呼吸法 & $73(8.9)$ \\
音楽療法 & $30(3.6)$ \\
ペットセラピー & $4(0.5)$ \\
イメージ療法 & $2(0.2)$ \\
漸進的筋弛緩法 & $2(0.2)$ \\
回想療法 & $2(0.2)$ \\
日記療法 & $2(0.2)$ \\
催眠療法 & $1(0.1)$ \\
読み語り療法 & $1(0.1)$
\end{tabular}

引用文献 5) より引用一部改変

は，マッサージが 592 名 $(71.8 \%)$ で最も多く，次いで 罨法が 357 名 (43.3\%), 足浴が 335 名 (40.7\%) であり, その他, 意図的タッチ, アロマセラピー, リンパドレナー ジがよく実施されていた.イメージ療法, 漸進的筋弛緩 法, 回想療法, 日記療法, 催眠療法, 読久語り療法の実 施者が 1〜2名あった.

1) 身体的症状に対して実施されている CAM（表 6-1）

よく実施するCAM の実施目的について尋悋た結果, 痛又の緩和を目的に，マッサージが 367 名 (44.5\%) で 最も多く, 次いで罨法が 261 名 (31.7\%), 意図的タッチ が 141 名（17.1\%）の看護師に実施されていた．全身倦 㤐感は, マッサージが 352 名 (42.7\%), 足浴が 101 名 (12.3\%)，意図的タッチが 91 名 (11.0\%)，アロマセラ ピー，罨法が実施されていた。 下肢のだるさに対しては マッサージが 491 名 (59.6\%), 足浴が 275 名 (33.4\%), 罨法が 116 名（14.1\%）に行わ秃て招り，その他に意図 的タッチ，アロマセラピー，リンパドレナージが実施さ れていた. 不眠に対してはマッサージが 183 名 (22.2\%), 足浴が 124 名 (15.0\%), 意図的タッチが 117 名 (14.2\%) に実施されていた。呼吸困難に対しては，マッサージ， 意図的タッチ, 呼吸法が行われ, 腹部膨満および便秘に 対してはマッサージや罨法が多く実施されていた，食欲 不振, 嘔気や嘔吐に対して CAM を実施している者は少 なかった。

2) 精神的症状等に対して実施されている CAM（表 6-2）

不安の緩和を目的にして, 意図的タッチが 252 名 (30.6 \%)，マッサージが 245 名（29.7\%）に実施されていた. リラクセーションの目的にマッサージが 276 名 (33.5\%),
足浴が 171 名 (20.8\%), 意図的タッチが 112 名 (13.6\%), アロマセラピーが 109 名（13.2\%）飞行われて打り，気 分転換の目的にマッサージが 195 名 (23.7\%), 足浴が 193 名 (23.4\%), アロマセラピーが 89 名 (10.8\%) 飞行 われていた。抑らつ，せん妄や意識障害に対しては意図 的タッチが行われていたが実施している看護師の数は少 なかった。

3) 人間関係の構築のために実施されている CAM（表 62)

患者と看護者間の人間関係の構築を目的にして実施さ れている CAM は, マッサージが 197 名 (23.9\%), 意図 的タッチが 171 名 (20.8\%) であり, 足浴, アロマセラ ピー，罨法などが実施されていた。

\section{CAM を実施する上での問題点（表 7）}

実施上の問題点は，「技術が未熟」が 592 名（71.8\%) で最も多く，次いで「時間の不足」が 425 名 (51.6\%)で あり「効果の評価ができていない」が 330 名 (40.0\%), 「継続して実施できない」が 327 名 (39.7\%) であった. 問題がないと回答した者は 55 名（6.7\%）であった.

\section{6. 今後身につけたいCAM（表 8）}

今後身につけたい CAM については，対象者全員から 回答を得た、CAMを実施したことがないと回答した者, 関心がない，必要性がない等の回答をした者も身につけ たいCAM があった。

緩和ケア病棟の看護師が今後身につけたい CAM は, リンパドレナージが 460 名 $(50.7 \%)$ で最も多く, 次い でアロマセラピーが 379 名 $(41.8 \%)$ ， マッサージが 220 名 $(24.3 \%)$, 呼吸法が 191 名（21.1\%）であった。瞑想 療法, バイオフィードバック, 催眠療法などを身につけ たいといら回答が $5 \%$ 前後認められた.

\section{CAM に関する要望}

\section{1) 習得する上での要望}

要望の自由回答は看護師 269 名から回答があり,のベ 388 件の要望があった。講習会・セミナーの開催に関す る要望が最も多く, 183 件 (68.1\%) であり, 開催回数を 多くしてほしい，地方での開催を要望していた，次いで 多かったのは講習会・セミナーの内容に関する要望が 77 件（28.6\%）であり，実技を中心にしたプログラム，技 法・技術の専門的な内容を求めていた。ささらに，勤務の 配慮や費用の助成等のサポート体制の充実の要望が 30 件（11.2\%）あった。

\section{2) 実施する上での要望}

要望の自由回答は看護師 139 名から回答があり, のベ 

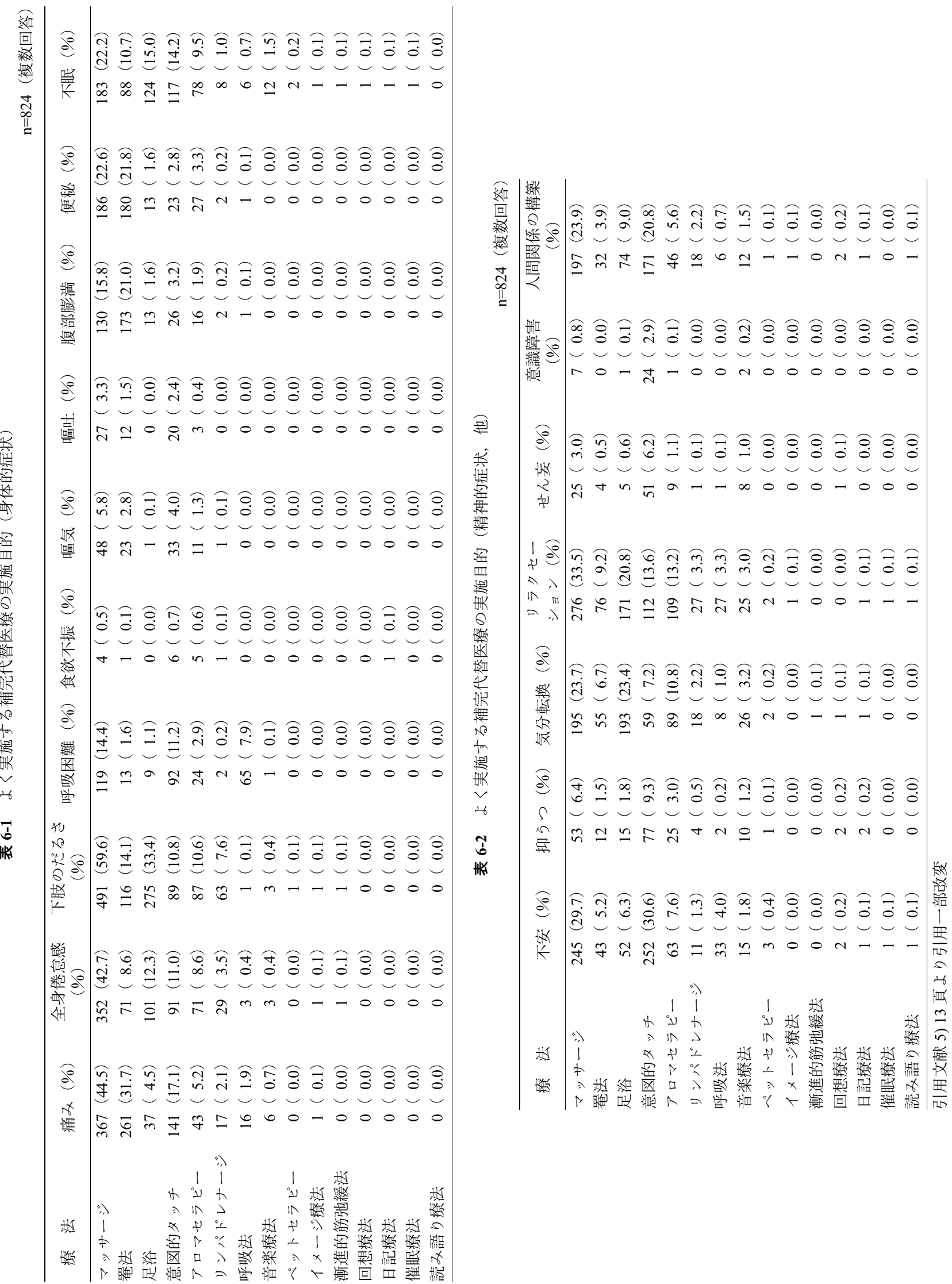
表 7 補完代替医療を実施する上での問題点 $\mathrm{n}=824$ （複数回答）

\begin{tabular}{|c|c|c|c|}
\hline 閌 & 題 点 & & $(\%)$ \\
\hline \multirow[t]{8}{*}{ 有 } & 技術が未熟 & 592 & $(71.8)$ \\
\hline & 時間の不足 & 425 & $(51.6)$ \\
\hline & 効果の評価ができていない & 330 & $(40.0)$ \\
\hline & 継続して実施できない & 327 & $(39.7)$ \\
\hline & 実施の判断が難しい & 215 & $(26.1)$ \\
\hline & スタッフの協力が得られない & 33 & $(4.0)$ \\
\hline & 金銭面に負担がある & 77 & $(9.3)$ \\
\hline & その他* & 19 & $(2.3)$ \\
\hline 無 & & 55 & ( 6.7$)$ \\
\hline
\end{tabular}

* 知識不足 6 , マンパワー不足 4 など

引用文献 5) より引用

表 8 今後身につけたい補完代替医療

$\mathrm{n}=907$ （複数回答）

\begin{tabular}{lc}
\hline \multicolumn{1}{c}{ 目 } & $(\%)$ \\
\hline リンパドレナージ & $460(50.7)$ \\
アロマセラピー & $379(41.8)$ \\
マッサージ & $220(24.3)$ \\
呼吸法 & $191(21.1)$ \\
音楽療法 & $154(17.0)$ \\
自律訓練法 & $118(13.0)$ \\
セラピューティックタッチ & $106(11.7)$ \\
ペットセラピー & $86(9.5)$ \\
漸進的筋弛緩法 & $85(9.4)$ \\
イメージ療法 & $76(8.4)$ \\
催眠療法 & $64(7.1)$ \\
回想療法 & $61(6.7)$ \\
瞑想療法 & $59(6.5)$ \\
意図的タッチ & $52(5.7)$ \\
読み語り療法 & $51(5.6)$ \\
バイオフィードバック & $41(4.5)$ \\
足浴 & $33(3.6)$ \\
日記療法 & $31(3.4)$ \\
罨法 & $29(3.2)$ \\
その他* & $12(1.3)$ \\
\hline
\end{tabular}

*カラーセラピー4, リフレクソロジー 2 など

引用文献 3) 145 頁より引用一部改変

186 件の要望があった. 人・時間の確保に関する要望が 約半数であった. 実施や評価の基準の明確化や有効性の 検証などのエビデンスが法しいという要望が 31 件 $(22.3$ $\%$, 施設, 上司の理解やスタッフの協力などのサポート 体制の充実が 28 件 (20.1\%) であった。 他，専門家によ るフォロー, 保険の認可や金銭面の配慮などの要望が あった。

\section{VI. 問題点と今後の課題}

緩和ヶア病棟に打いて, CAM は気分転換やリラクセー ションなどの癒しの技術としてだけではなく，痛みや全 身倦总感，下肢のだるさなどの身体的症状や，不安など の精神的症状の緩和を目的にして実施されていた。 そし て，緩和したい症状，苦痛によって使用される CAM の 種類が異なっていた。 つまり，看護師が症状に応じて CAM を選択し，CAMを使い分けていると考えられる.

看護基礎教育で習得する機会があったマッサージ，足 浴，罨法がよく実施されていた，講習会・セミナーに参 加しての習得はアロマセラピー, 呼吸法, リンパドレナー ジが多かったが，院内の伝達講習会や勉強会，技術を有 する知人，友人に教えてもらった，あるいは専門書，手 引書, 視聴覚教材を使用して独学している者も多かった. さらに，他の習得方法と併せて自己流といら回答も多 かった．CAM は技法・技術によって留意事項や禁忌事 項があり ${ }^{2)}$, 緩和ケア病棟に入院中の対象者に CAM を行 う場合は，手技的に難しくないものであっても，さらに 注意が必要となる。したがって，今後はCAM の独学や 自己流による実施の問題についての検討が必要であると 考えられる.

CAM を実施する場合，それらの技法・技術を習得す ることが前提となり，看護師自らが学習する動機付けと ともに教育の機会を設けることが重要である. Gaydos ${ }^{6}$ は学部学生, 扎よび卒後や継続教育に拈けるレベルに応 じた CAM の教育の必要性を述べている.アメリカでは 学部教育に扣いて指圧，セラピューティックタッチ，ア ロマセラピー, イメージ療法, 音楽療法, マッサージ, リラクセーションなどの教育が多くの看護系大学で行わ れている7). さらに，アメリカホリスティック看護協会 がホリスティックケアとそれに関するガイドラインを定 めて扣り，協会が推奨する認定プログラム ${ }^{8)}$ が継続教育 として実施されている.

わが国において，新設の看護系大学や銊尒大学に併設 された看護学部では東洋医学や CAM の講義をカリキュ ラムに導入しているところがあり，さらに，マッサー ジ9)やリラクセーション10)，アロマセラピー11)を取り入 れた演習・実習を実施しているところがある，従来の基 礎看護教育で行われていた罨法や足浴などの看護技術以 外に CAM の概念を取り入れた教育が実施されるよらに なってきた，また，日本看護協会によるホスピスケアの 認定看護師教育 ${ }^{12)}$ の中にリラクセーションやリンパド レナージなどの項目がある。しかし，看護基礎教育，継 続教育の中で CAM の教育が体系的に実施されていると はいえない状況である。 
現在 CAM を行ったことがないと回答した者や関心が ないと回答した者も身につけたいCAM をあげており， 緩和ヶア病棟の看護師には，CAM を身につけたいとい らニーズがあった。しかし，緩和ケア病棟の看護師が身 につけたいと思っているリンパドレナージなどは，看護 基礎教育で学習機会が乏しく，個々で知識や手技を習得 する必要があるものが多い。 また，それらの講習会やセ ミナーなどは都市で実施されることが多いため，習得の 要望として講習会の回数の増加や身近な場所，地方での 開催といら要望に反映されていると思われる，看護基礎 教育に敃いて CAM の教育の機会があること, そして卒 後に継続教育として CAM の教育の機会があることが望 ましい。

実施上の問題点として「技術が未熟」であることとと もに「効果の評価ができていない」と感じている看護師 が多かった，看護に拈ける CAM の効果の検証は端緒を 開いたところであり，緩和ケアとしての CAM のエビデ ンスを明らかにすることが大きな課題といえる.

本研究の調査時 146 施設であった緩和ケア病棟（届出 受理施設）が 1 年余りで 17 施設増の 163 施設（平成 18 年 12 月 1 日現在)になった. 今後も緩和ヶア病棟の増加 が考えられ，緩和ヶア病棟で CAM を実施する看護師は 多くなると予想される. したがって, 看護ケアとして CAM を実施していくためには, 各種 CAM のエビデンス の蓄積と看護基礎教育・継続教育に打忊 CAM の教育 プログラムの充実が必要であると考えられる.

\section{参 考 文 献}

1) マラヤ・スナイダー (著)。尾㟝フサ子，早川和生（監訳）. 看護独自の介入一広がるサイエンスの技術. 大阪. メディ 力出版. 1994.

2) Snyder M, Lindquist R（編）。野島良子，冨川孝子（監訳）。 心とからだの調和を生むケア 看護に使う28の補助的/代 替的療法. 東京. 医学書院. 1999.

3) 新田紀枝，川端京子，高橋晃子ら。ホスピス・緩和ケア病 棟看護師の代替療法の習得の現状と要望. 第37回日本看護 学会論文集 (看護教育). 2007; 144-146.

4) 新田紀枝，川端京子，高橋晃子ら。ホスピス病棟に打ける 「ナースの代替療法の実施」の現状と課題に関する調査報告 書. 2006

5) 新田紀枝，川端京子，高橋晃子ら．緩和ヶア病棟看護師の 代替療法の実施の現状に関する調査. 第37回日本看護学会 論文集（成人看護 II)。(印刷中).

6) Gaydos HL. Complementary and alternative therapies in nursing education: trends and issues. Online Journal of Issues in Nursing 2001; 6(2).

7) 手島 恵. 代替／補完療法の実践と看護教育. 看護教育. 1999; 40(8): 630-633.

8) http://www.ahna.org/about/statements.html

9) 田口玲子, 渡辺岸子, 尾㠃フサ子ら. 看護療法としてのマッ サージに関する検討. 新潟大学医学部保健学科紀要. 2003; 7(5): 653-668.

10) 小板橋喜久代，柳奈津子「「ころと身体の相関を整えるケ ア」の実験実習．看護展望．2004; 29(11): 1278-1285.

11）小濱優子，荒木こずえ，島田祥子ら．看護基礎教育におけ る代替療法の活用に関する一考察一メディカルアロマセラ ピーを中心として一．川崎市立看護短期大学紀要．2006; 11(1): 61-68.

12) http://www.nurse.or.jp/kiyose/kango/gakka04.html 


\begin{abstract}
Level of Awareness and Practice of Complementary and Alternative Medicine in Nursing - Survey of Nurses in Palliative Care Units with Regard to Training and Practice of Complementary and Alternative Medicine-

\author{
Norie NITTA $^{1}$, Kyoko KAWABATA ${ }^{2}$ \\ ${ }^{1}$ Course of Health Science, Graduate School of Medicine, Osaka University \\ ${ }^{2}$ Osaka City University School of Nursing
}

A nationwide survey of nurses in palliative care units was conducted to clarify the present state of the profession with regard to training and practice of complementary and alternative medicine (CAM). Questionnaires were completed by 907 nurses (return rate: $77.3 \%$ ). Approximately $90 \%$ of respondents had implemented CAM as an element of nursing care, and gave high scores for interest in CAM, perception of physical and psychological effects of, as well as need for, these medicines. Among the most commonly used treatments were massage, foot baths, and application of heat/cold, all of which nurses had the opportunity to learn as undergraduates. Different CAMs were used depending on the patient's physical/psychological symptoms. Problems indicated in regard to carrying out these treatments included: "Insufficient skill level," "Insufficient time," and "Cannot evaluate results." Many respondents indicated a desire for further CAM training. The results of this survey indicate that in order for CAM to be effectively incorporated into nursing care it will be necessary to accumulate evidence regarding various CAMs, and to improve CAM training programs for undergraduates and continuing education.
\end{abstract}

Key words: palliative care unit, nursing care, complementary and alternative medicine, nurse 